DOI:10.17951/h.2020.54.4.31-40

\begin{tabular}{lcc}
\hline \multicolumn{3}{c}{ A N N A L E S } \\
UNIVERSITATIS MARIAE CURIE-SKŁODOWSKA \\
LUBLIN - POLONIA \\
VOL. LIV, 4 & SECTIOH H \\
\hline
\end{tabular}

\title{
SYLWIA FRYDRYCH
}

sylwia.frydrych@sgh.waw.pl

Warsaw School of Economics. Collegium of Management and Finance

162 Niepodległości Av., 02-554 Warsaw, Poland

ORCID ID: https://orcid.org/0000-0002-1215-49500

\section{The Role of Credit Rating of the Eurobond Issuers from Central and Eastern Europe}

Keywords: credit rating; Eurobond; creditworthiness assessment

JEL: G12; G15; G24

How to quote this paper: Frydrych, S. (2020). The Role of Credit Rating of the Eurobond Issuers from Central and Eastern Europe. Annales Universitatis Mariae Curie-Sktodowska, sectio H-Oeconomia, Vol. 54, No. 4.

\footnotetext{
Abstract

Theoretical background: The increase in the issuance of Eurobonds by the issuers from Central and Eastern Europe has become a reason for considering the impact of the issuer's creditworthiness assessment on the interest rate of the coupon of the issued debt instruments.

Purpose of the article: The aim of the study was to assess whether having a creditworthiness assessment from more than one agency affects the interest rate on the Eurobond coupon. This objective was achieved through the process of analysis of the ratings assigned by the rating agencies. Based on the analysis of the literature and the available data, the research hypothesis was developed and verified in an empirical study. The results were analyzed in the discussion section.

Research methods: The credit ratings for the Eurobonds corporate and government issuers, announced on the issue date, have been analyzed. The analysis covered the fixed interest rate debt instruments issued in EUR in the years 2005-2020 (the first half of the year). The empirical research was carried out using the observation method, the analysis of source documents, and the method of deduction.

Main findings: The results of the conducted research indicate that the coupon rate is not affected by the number of ratings given to the issuer. Due to the fact that the lowest average coupon interest in 2005-2020
} 
was held by Eurobonds of the issuers with one credit rating, there is no need for an additional creditworthiness assessment by other agencies, and for any additional costs to be incurred by the issuer. It is one of the few studies on the Central and Eastern Europe market of which the author is aware.

\section{Introduction}

Eurobonds, as debt instruments, include an issuer's promise to pay a coupon to bondholders on the dates specified in the terms of the issue. Holders of debt securities are exposed to several types of risk, including the default risk. The credit rating is one of the risk indicators of the debt default (Fabozzi, 2007). Moreover, the ratings are carried out by the specialized rating agencies, mostly Standard \& Poor's (S\&P), Moody's and Fitch Group, that should be independent and objective.

The credit rating agencies (CRAs) act as intermediaries between the issuers and the investors by assessing the creditworthiness of the issuers around the world (Bongaerts, Cremers, \& Goetzmann, 2012). The rating agencies play an important role in the development of the capital market providing opinions on issuers to investors (Opp, Opp, \& Harris, 2013). Their opinion affects the issuers' access to capital and the cost of capital (SEC, 2003).

The aim of this paper is to analyse how the credit rating of the issuer influences the coupon of Eurobond. The goal of this article is to examine whether is it enough for the issuers to have a credit rating from one agency, or is it better to have a credit rating from two or even three agencies. This paper contributes to the literature on the relationship between the number of issuer ratings and Eurobond coupon. Therefore, whether a higher number of issuer ratings, incurring additional costs, results in a lower Eurobond coupon. In view of the above, the analyses was carried out for the Eurobonds issued by the Central and Eastern Europe (CEE) corporate and government issuers, which at the time of issue were not part of the euro area.

The article presents the rating of issuers on the issuance date of Eurobonds. The period of analyses covers Eurobonds which were issued in the period of 2005-2020 (the first half of the year). The work is based on the number of the instruments outstanding as of 30 June 2020 from the cbonds.pl platform, and the data from websites of the agencies: S\&P, Moody's, and Fitch Group. Only the instruments issued in EUR and with a fixed interest rate were taken into consideration.

The first part of the text presents an overview of the literature on the subject, with particular emphasis on the analysis of credit ratings by the three largest agencies. In the empirical part, the difference when it comes to the given credit ratings between the agencies was analyzed. Moreover, the paper captures the impact of having the ratings assigned by the rating agencies on the interest rate of the Eurobond coupon. The article ends with the conclusions regarding the role of credit rating of the CEE Eurobond issuers. 


\section{Literature review}

The creditworthiness assessment is essential if the entity intends to obtain financing from the international market. The credit rating can be defined as an "investment risk classification scheme" (Dziawgo, 2010). CRAs are concerned with the prediction of the probability of default of debt issuers (IOSCO, 2004). The credit ratings have a large impact on the access to finance and its cost.

An extensive literature has investigated the relationship between changes in the borrowers' credit ratings, as disclosed by rating agencies and the impact of these changes on the financial instruments prices in response to these events. The topic of the influence of credit ratings was a subject of the empirical studies many times in the past (Hand, Holthausen, \& Leftwich, 1992; Avramov, Chordia, Jostova, \& Philipov, 2007; Galil \& Soffer, 2011). Most of research focuses on the response of the common stocks to the rating changes (Griffin \& Sanvicente, 1982; Cornell, Landsman, \& Shapiro, 1989; Goh \& Ederington, 1999). Several studies have analyzed the negative impact of downgrading the credit rating on the bond prices (Dichev \& Piotroski, 2001; Vassalou \& Xing, 2005; Gande \& Parsley, 2005; Jorion \& Zhang, 2010; Chung, Frost, \& Kim, 2012; Afonso, Furceri, \& Gomes, 2012). Unlike downgrades, some research has shown a relatively weak market reaction to the rating increases (Steiner \& Heinke, 2001; Cantor, 2004; Norden \& Weber, 2004; Behr \& Güttler, 2008; Bannier \& Hirsch, 2010). However, very few studies focus on assessing the creditworthiness of an issuer at the time of issuing Eurobonds.

The article deals mainly with the credit rating of the Eurobonds issuers. According to the definition provided by Choudhry (2006), "Eurobonds are bonds that are subscribed and sold on different international markets simultaneously, usually by international banking syndicates". While CRAs have different concepts and measures of probability of default, various studies comparing Moody's, Fitch, S\&P ratings showed strong similarities in credit ratings (Cantor \& Packer, 1996; Ammer \& Packer, 2000, Jewell \& Livingston, 2000). The rating reflects the probability of the timely payment of the Eurobond coupon by the issuer.

Table 1. The symbols of ratings assigned by CRAs

\begin{tabular}{|c|c|c|c|}
\hline $\mathrm{S} \& \mathrm{P}$ & Fitch & Moody's & Rating description for category \\
\hline \multicolumn{3}{|c|}{ Investment grade } & \\
\hline AAA & AAA & Aaa & Highest quality, lowest credit risk \\
\hline $\mathrm{AA}$ & AA & $\mathrm{Aa}$ & High quality, very low credit risk \\
\hline A & $\mathrm{A}$ & $\mathrm{A}$ & Upper medium grade quality, low credit risk \\
\hline $\mathrm{BBB}$ & BBB & Baa & Medium grade quality, moderate credit risk \\
\hline \multicolumn{3}{|c|}{ Speculative grade } & \\
\hline $\mathrm{BB}$ & $\mathrm{BB}$ & $\mathrm{Ba}$ & Speculative, substantial credit risk \\
\hline $\mathrm{B}$ & $\mathrm{B}$ & $\mathrm{B}$ & Speculative, high credit risk \\
\hline $\mathrm{CCC}$ & $\mathrm{CCC}$ & Caa & Speculative and in poor standing, very high credit risk \\
\hline $\mathrm{CC}$ & $\mathrm{CC}$ & $\mathrm{Ca}$ & Highly speculative and likely in or near default \\
\hline $\mathrm{C}$ & $\mathrm{C}$ & $\mathrm{C}$ & Lowest rated and typically in default \\
\hline
\end{tabular}

Source: S\&P, Fitch and Moody's Investors Service materials. 
Differences in the opinions of the agencies are to be expected and different companies use various sets of the symbols to indicate the assigned rating. However, the differences between the companies are slight, and it is quite easy to see the relationship between different symbols. As can be seen in Table 1, the scales are very similar. The first letter is the same for each company in each symbol. Only the rest of the symbols vary. As it is shown, the ratings have been divided into two large categories: the investment and speculative grade.

\section{Research problem}

The above considerations led to the identification of the research problem which is the impact of the number of ratings of an issuer on the coupon of Eurobonds. It should be emphasized that not all the ratings are paid by the issuers. In addition to the solicited assessments, there are the unsolicited assessments of the issuer's creditworthiness. These are the ratings in which the credit rating agency independently assesses the creditworthiness of the issuer without being paid by the issuer. According to the study by Baker and Mansi (2001), only about $17.8 \%$ of companies in their survey sample reported receiving the unsolicited ratings. Therefore, the author assumes in the study that all creditworthiness assessments were ordered by the issuers.

The up-to-date studies in the literature have referred to the market reaction to changes in the rating of Eurobonds. So far, no research has been performed focusing on the relation between the number of credit ratings assigned to the issuer from Central and Eastern Europe and the average coupon of its Eurobonds. The presented considerations lead to the definition of the research problem which is the impact of the number of credit ratings awarded by the largest rating agencies to the issuers from Central and Eastern Europe on the coupon interest rate on their Eurobonds. On this basis, the following hypothesis was formulated: The Eurobond issuers with more than one creditworthiness assessment bear the lower cost of the debt.

The above-mentioned relation is worth examining, as the issuers could pay more than one agency for assigning their ratings. For this purpose, the paper analyzes a coupon rate on Eurobonds of the issuers who were given creditworthiness assessment from one or more CRAs.

\section{Research methods}

The analysis covers the credit rating of the corporate and government issuers from Central and Eastern Europe issued in the years 2005-2020 (the first half of the year 2020). The study includes only the Eurobonds which were in the circulation on 30 June 2020. The research material in this paper includes - apart from the analysis of literature - a method of observation, analysis of source materials, and a method 
of deduction. The paper utilizes the data from the cbonds.pl platform and websites of issuers. The author has examined which agencies most often gave the ratings to the CEE Eurobonds issuers. Moreover, it has been checked whether the issuers were rated by one or more agencies and what rating was given most frequently. The analysis was carried out using the Spearman rank correlation coefficient. In the next step, the author analyzed from which agency the issuers received the highest and from which the lowest ratings. Finally, the study assessed whether having a rating from one, two, or three agencies has an impact on the coupon rate.

For this purpose, 314 issues of 81 issuers of Eurobonds have been analyzed. The analysis excluded the float coupon due to the fact that $96 \%$ of the bonds have fixed coupon. Moreover, the research was only conducted for EUR as a result of $78 \%$ of the issues being carried out in this currency. In view of the above assumptions, the analysis covers 231 Eurobonds issued by 71 issuers from the CEE countries.

\section{Results and discussions}

In case of 71 issuers of the sample group, all the issuers were assigned a rating. As can be seen in Table 2, one agency gave a credit rating to $32 \%$ of the issuers; two agencies gave a credit rating to $38 \%$ of the issuers; while three agencies gave a credit rating to $30 \%$ of the issuers. There are no significant preferences regarding the number of issuers' ratings.

Table 2. The number of ratings assigned by CRAs

\begin{tabular}{|c|c|c|c|}
\hline Moody's & S\&P & Fitch & Issuers \\
\hline$\checkmark$ & & & 7 \\
\hline & $\checkmark$ & & 8 \\
\hline & & $\checkmark$ & 13 \\
\hline$\checkmark$ & $\checkmark$ & & 8 \\
\hline$\checkmark$ & & $\checkmark$ & 6 \\
\hline & $\checkmark$ & $\checkmark$ & 21 \\
\hline
\end{tabular}

Source: Author's own study based on the cbonds.pl platform data.

The data in Table 1 shows that Moody's awarded the highest number of ratings $-69.01 \%$. S\&P, on the other hand, assigned $67.61 \%$ and Fitch $-60.56 \%$ of ratings. The second stage of the research focused on the difference in the credit ratings between the agencies.

Figure 1 shows that $\mathrm{Baa} / \mathrm{BBB} / \mathrm{BBB}$ rating prevails among the ratings given to the issuers. The moderate credit risk was awarded 60 times, with 22 issuers receiving such ratings from Moody's and 22 issuers receiving such ratings from Fitch. As can be seen from the figure, 33 issuers received the assessment of the upper medium grade quality (A/A/A), which appeared 12 times in Moody's and 12 times in Fitch, whereas 
the high quality credit rating (Aa/AA/AA), as well as speculative, high credit risk rating $(B / B / B)$ were received by 15 issuers. However, none of the above-mentioned agencies assigned the highest quality credit rating (Aaa/AAA/AAA) or the lowest rating $(\mathrm{Ca} / \mathrm{C} / \mathrm{C})$. Moreover, $\mathrm{S} \& \mathrm{P}$ withdrew the assessment given to four issuers.

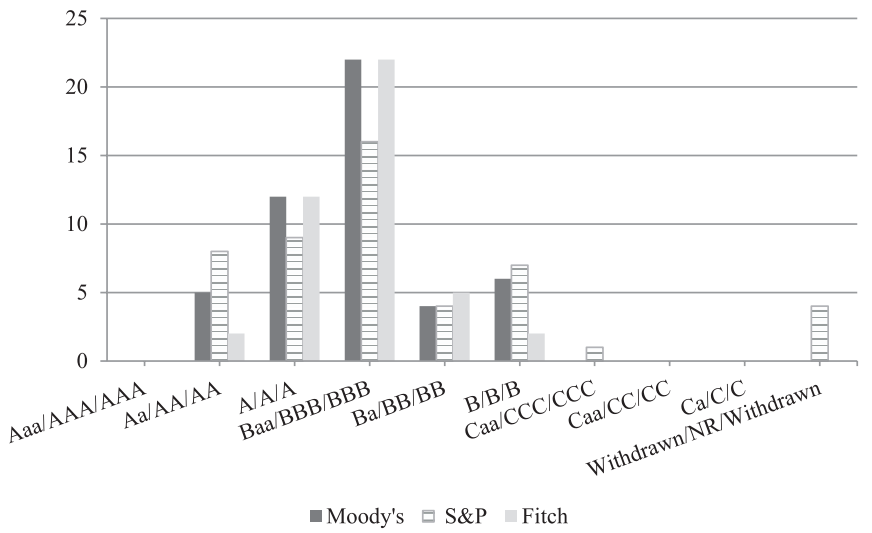

Figure 1. Ratings assigned by Moody's, S\&P and Fitch

Source: Author's own study based on the cbonds.pl platform data.

Furthermore, there is some difference in the rating scales between the agencies. Moody's rated higher than S\&P in $35.48 \%$ of the cases and higher than Fitch in $32.00 \%$ of the cases. Moody's ratings were lower than S\&P ratings in $25.81 \%$ of the cases and lower than Fitch ratings in $24.00 \%$ of the cases, whereas Moody's gave similar ratings to $\mathrm{S} \& \mathrm{P}$ in $38.71 \%$ of the cases and similar ratings to Fitch in $44.00 \%$ of the cases. When comparing S\&P with Fitch ratings, $60.71 \%$ of the issuers received the same rating. S\&P ratings were higher than Fitch ratings only in about $10.71 \%$ of the cases and lower than Fitch ratings in $28.57 \%$ of the cases (Figure 2).

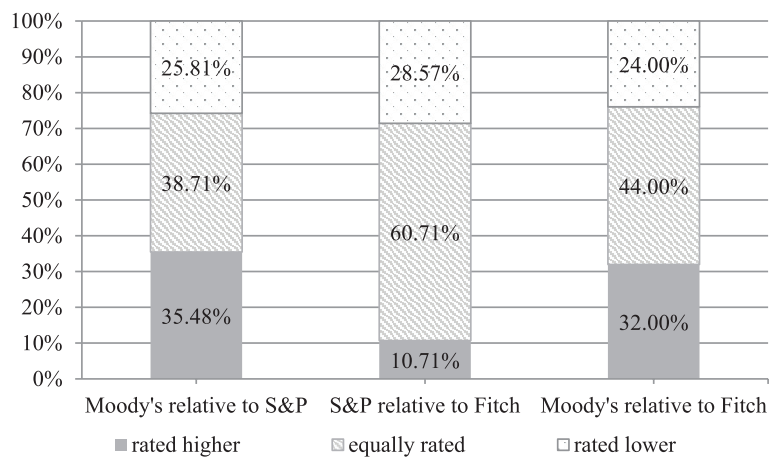

Figure 2. Rating differences between agencies 
Furthermore, the analysis of the ratings awarded to the issuers by individual agencies was carried out, in order to check which agency gave the highest and the lowest credit ratings. For this purpose, the issuers which received the ratings from two or three agencies were analyzed. The issuers which received the rating only from one agency were excluded from this sample. The analysis does not also include the situations where the assessment of the agencies was the same.

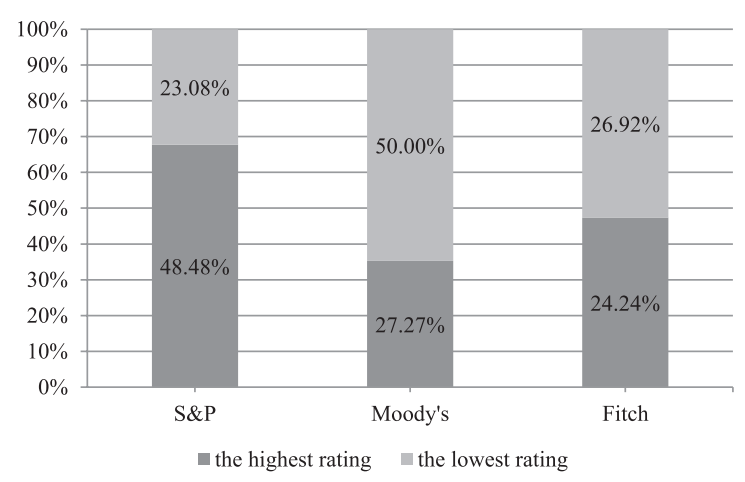

Figure 3. The highest and the lowest rating awarded by agencies

Source: Author's own study based on the cbonds.pl platform data.

The comparison of the highest and lowest credit rating awarded by S\&P, Moody's and Fitch led to some conclusions. S\&P gave the highest rating to $48.44 \%$ of the issuers, whereas Moody's - only to $27.27 \%$ of the issuers. When analyzing the lowest grade received by the issuers, the situation looks different. Moody's gave the lowest rating to $50.00 \%$ of the issuers, while $\mathrm{S} \& \mathrm{P}$ - to $23.08 \%$ of the issuers of Eurobonds from Central and Eastern Europe. Fitch ranks in the middle with the highest rating awarded to $24.24 \%$ and the lowest rating given to $26.92 \%$ of the issuers.

The last stage of research covers the influence of rating on the coupon rate. The average coupon of issuers' debt instruments was analyzed depending on the number of ratings given by the individual agencies. Since 2013, the issuers have had ratings given by one, two or three agencies. The previous years were excluded due the fact that there were no ratings from just one agency. The aim of the study is to verify in each year the impact of the number of ratings on the coupon rate also in the case of having a credit rating from just one agency. Therefore, the study covers the years 2013-2020 (the first half of the year). 
Pobrane z czasopisma Annales H - Oeconomia http://oeconomia.annales.umcs.pl Data: 26/04/2023 13:00:26

Table 3. Average coupon rates of issuers' debt instruments depending on the number of ratings (\%)

\begin{tabular}{|l|c|c|c|c|c|c|c|c|c|}
\hline \multicolumn{1}{|c|}{ Year } & 2013 & 2014 & 2015 & 2016 & 2017 & 2018 & 2019 & 2020 & $\begin{array}{c}\text { Average coupon } \\
2013-2020\end{array}$ \\
\hline $\begin{array}{l}\text { Rating from one } \\
\text { agency }\end{array}$ & 3.88 & 2.56 & 2.63 & 3.25 & 1.66 & 1.42 & 2.75 & 1.75 & 2.13 \\
\hline $\begin{array}{l}\text { Rating from two } \\
\text { agencies }\end{array}$ & 3.02 & 3.49 & 3.85 & 4.42 & 3.38 & 4.39 & 2.55 & 2.84 & 3.55 \\
\hline $\begin{array}{l}\text { Rating from } \\
\text { three agencies }\end{array}$ & 3.96 & 3.08 & 2.10 & 2.00 & 2.20 & 2.09 & 2.78 & 1.66 & 2.30 \\
\hline
\end{tabular}

Source: Author's own study based on the cbonds.pl platform data.

Table 3 represents the average coupon of issuers' debt instruments depending on the number of ratings by years. According to data, the lowest coupon rates have changed over the years. One can interpret the data in several ways. The peak of the average coupon rate was noted in 2013 - this applies to the assessment of the credit rating from one agency $-3.88 \%$ and from three agencies $-3.96 \%$, whereas in 2016 , the highest average coupon rate of the Eurobonds was up to $4.42 \%$ for issues rated by two agencies. The lowest average coupon rate was in 2018 - for rating only from one agency, in 2019 - for rating from two agencies and in 2020 - for rating from three agencies. Taking into account the above, the average interest rate on coupons of Eurobonds of the issuers, who had a rating, was calculated. The following results were obtained: the issuers holding credit rating only from one agency issued Eurobonds with the lowest average interest rate of the coupon in the years 2013-2020-2.13\%, whereas Eurobonds with the highest average coupon interest in the years 2013-2020 were issued by the entities with the credit ratings from two agencies $-3.55 \%$.

The article also examines the relationship between the average coupon rate of issuers' debt instruments and the number of ratings using the Spearman rank correlation coefficient. Table 4 reports the correlation coefficient is equal to 0.0546 . Therefore, average coupon rates of issuers' debt instruments has positive weak correlations with the number of ratings.

Table 4. The Spearman rank correlation coefficient

\begin{tabular}{|c|c|c|}
\hline Variables & Correlation coefficient & $p$-value \\
\hline average coupon rates of issuers' debt instruments / the number of ratings & 0.054 & 0.41 \\
\hline
\end{tabular}

Source: Author's own study based on the cbonds.pl platform data.

Furthermore, a test of the significance of the correlation coefficient has been performed. The obtained $p$-value is equal to 0.41 . With a significance level of 0.05 , there are no grounds to reject the null hypothesis, the correlation coefficient between the variables is statistically insignificant. 


\section{Conclusions}

The goal of this paper was to analyze whether the issuer of Eurobonds should have the credit rating from only one agency or more, and to verify the impact it has on the coupon interest rate, which basically means whether a higher number of issuer ratings, incurring additional costs, results in a lower Eurobond coupon. The analysis of 231 issued Eurobonds of 71 issuers from Central and Eastern Europe in the years 2013-2020 leads to the numerous conclusions.

Firstly, most issuers have a rating of the two agencies $-38 \%$; Moody's gave the highest number of ratings $-69.01 \%$. Secondly, the medium grade quality rating $(\mathrm{Ba} /$ $\mathrm{BBB} / \mathrm{BBB}$ ) was assigned most frequently. The highest ratings were given by the S\&P, whereas the lowest - by Moody's. These results are also somewhat surprising due to the number of ratings given by Moody's. However, the issuers seem to take other information into account, i.e. mainly related to the costs when selecting a credit rating agency. Thirdly, the number of ratings given to the issuer does not affect the coupon rate. The lowest average coupon interest in 2013-2020 was held by Eurobonds of the issuers with one credit rating. This finding suggests that one assessment of the issuer's creditworthiness is sufficient. There is no reason for the additional creditworthiness assessment by other agencies and for incurring additional costs by the issuer. This has been confirmed by the test of the Spearman rank correlation coefficient. Therefore, the hypothesis - Eurobond issuers with more than one creditworthiness assessment bear the lower cost of the debt - has been verified negatively.

The source literature does not include many studies comparing the credit rating of the issuers from Central and Eastern Europe. The similar analyses may be conducted also for the issuers from other regions of the world. The further research should also explain the impact of changing credit rating of the issuer during the Eurobonds term.

\section{References}

Afonso, A., Furceri, D., \& Gomes, P. (2012). Sovereign credit ratings and financial markets linkages: Application to European data. Journal of International Money and Finance, 31(3).

doi:10.1016/j.jimonfin.2012.01.016

Ammer, J., \& Packer, F. (2000). How consistent are credit ratings? A geographic and sectoral analysis of default risk. International Finance Discussion Papers, 668.

Avramov, D., Chordia, T., Jostova, G., \& Philipov, A. (2007). Credit ratings and the cross-section of stock returns. Working Paper, EFA 2008 Athens Meeting.

Baker, K., \& Mansi, S. (2001). Assessing credit agencies by corporate bond issuers: The case of investment versus non-investment grade bonds. SSRN Working Paper.

Bannier, Ch.E., \& Hirsch, Ch.W. (2010). The economic function of credit rating agencies - what does the watchlist tell us? Journal of Banking \& Finance, 34(12), 3037-3049.

doi:10.1016/j.jbankfin.2010.07.002

Behr, P., \& Güttler, A. (2008). The informational content of unsolicited ratings. Journal of Banking \& Finance, 32(4), 587-599. doi:10.1016/j.jbankfin.2007.04.021 
Bongaerts, D., Cremers, K.J.M., \& Goetzmann, W.N. (2012). Tiebreaker: certification and multiple credit ratings. Journal of Finance, 67(1), 113-152. doi:10.1111/j.1540-6261.2011.01709.x

Cantor, R., \& Packer, F. (1996). Determinants and impact of sovereign credit ratings. Economic Policy Review, 2, 37-54.

Cantor, R. (2004). An introduction to recent research on credit ratings. Journal of Banking \& Finance, 28(11), 2565-2573.

Choudhry, M. (2006). Corporate Bond Markets: Instrument and Applications. Singapore: John Wiley \& Sons.

Chung, H., Frost, C., \& Kim, M. (2012). Characteristics and information of credit watches. Financial Management, 41(1), 119-158. doi:10.1111/j.1755-053X.2012.01180.x

Cornell, B., Landsman, W., \& Shapiro, A. (1989). Cross-sectional regularities in the response of stock prices to bond rating changes. Journal of Accounting, Auditing and Finance, 4(4). doi:10.1177/0148558X8900400403

Dichev, I., \& Piotroski, J. (2001). The long-run stock returns following bond ratings changes. Journal of Finance, 56(1), 173-203. doi:10.1111/0022-1082.00322

Dziawgo, D. (2010). Credit rating na międzynarodowym rynku finansowym. Warszawa: PWE.

Fabozzi, F. (2007). Bond Market, Analysis, and Strategies. New Jersey: Pearson Prentice Hall.

Galil, K., \& Soffer, G. (2011). Good news, bad news and rating announcements: An empirical investigation, Journal of Banking \& Finance, 35(11), 3101-3119. doi:10.1016/j.jbankfin.2011.04.010

Gande, A., \& Parsley, D. (2005). News spillovers in the sovereign debt market. Journal of Financial Economics, 75(3), 691-734. doi:10.1016/j.jfineco.2003.11.003

Goh, J., \& Ederington, L. (1999). Cross-sectional variation in the stock market reaction to bond rating changes. Quarterly Review of Economics and Finance, 39(1), 101-112.

Griffin, P., \& Sanvicente, A. (1982). Common stock returns and rating changes: a methodological comparison. Journal of Finance, 37(1), 103-119. doi:10.1111/j.1540-6261.1982.tb01098.x

Hand, J., Holthausen, R., \& Leftwich, R. (1992). The effect of bond rating agency announcements on bond and stock prices. Journal of Finance, 47(2). doi:10.2307/2329121

IOSCO (International Organization of Security Commissions, Technical Committee). (2004). Code of Conduct Fundamentals for Credit Rating. IOSCO Public Document 173. Retrieved from www.iosco. org/library/pubdocs/pdf/IOSCOPD180.pdf

Jewell, J., \& Livingston, M. (2000). The impact of a third credit rating on the pricing of bonds. Journal of Fixed Income, 10(3), 69-85. doi:10.3905/jfi.2000.319275

Jorion, P., \& Zhang, G. (2010). Information transfer effects of bond rating downgrades. Financial Review, 45(3), 683-706. doi:10.1111/j.1540-6288.2010.00266.x

Norden, L., \& Weber, M. (2004). Informational efficiency of credit default swap and stock markets: The impact of credit rating announcements. Journal of Banking \& Finance, 28(11), 2813-2843. doi:10.1016/j.jbankfin.2004.06.011

Opp, C.C., Opp, M.M., \& Harris, M. (2013). Rating agencies in the face of regulation. Journal of Financial Economics, 108(1), 46-61. doi:10.1016/j.jfineco.2012.10.011

SEC (U.S. Securities and Exchange Commission). (2003). Report on the Role and Function of Credit Rating Agencies in the Operation of the Securities Markets.

Steiner, M., \& Heinke, V. (2001). Event study concerning international bond price effects of credit rating actions. International Journal of Finance and Economics, 6(2), 139-157. doi:10.1002/ijfe.148

Vassalou, M., \& Xing, Y. (2005). Abnormal Equity Returns Following Downgrades. Working Paper. Columbia University. 